\title{
Origin and Characteristics of Massive Ground Ice on Herschel Island (Western Canadian Arctic) as revealed by Stable Water Isotope and Hydrochemical Signatures
}

\author{
Michael Fritz, ${ }^{1 *}$ Sebastian Wetterich, ${ }^{1}$ Hanno Meyer,${ }^{1}$ Lutz Schirrmeister, ${ }^{1}$ Hugues Lantuit ${ }^{1}$ and Wayne H. Pollard ${ }^{2}$ \\ 1 Alfred Wegener Institute for Polar and Marine Research, Potsdam, Germany \\ 2 Department of Geography and Global Environmental and Climate Change Centre, McGill University, Montreal, Canada
}

\begin{abstract}
Herschel Island in the southern Beaufort Sea is a push moraine at the northwestern-most limit of the Laurentide Ice Sheet. Stable water isotope $\left(\delta^{18} \mathrm{O}, \delta \mathrm{D}\right)$ and hydrochemical studies were applied to two tabular massive ground ice bodies to unravel their genetic origin. Buried glacier ice or basal regelation ice was encountered beneath an ice-rich diamicton with strong glaciotectonic deformation structures. The massive ice isotopic composition was highly depleted in heavy isotopes (mean $\delta^{18} \mathrm{O}$ : $-33 \%$; mean $\delta \mathrm{D}$ : $-258 \%$ ), suggesting full-glacial conditions during ice formation. Other massive ice of unknown origin with a very large $\delta^{18} \mathrm{O}$ range (from -39 to $-21 \%$ ) was found adjacent to large, striated boulders. A clear freezing slope was present with progressive depletion in heavy isotopes towards the centre of the ice body. Fractionation must have taken place during closed-system freezing, possibly of a glacial meltwater pond. Both massive ground ice bodies exhibited a mixed ion composition suggestive of terrestrial waters with a marine influence. Hydrochemical signatures resemble the Herschel Island sediments that are derived from nearshore marine deposits upthrust by the Laurentide ice. A prolonged contact between water feeding the ice bodies and the surrounding sediment is therefore inferred. Copyright (C) 2011 John Wiley \& Sons, Ltd.
\end{abstract}

KEY WORDS: massive ground ice; stable water isotopes; hydrochemistry; permafrost; Laurentide Ice Sheet

\section{INTRODUCTION}

Bodies of tabular massive ground ice (hereafter termed massive ground ice) defined as ground ice with a gravimetric ice content exceeding 250 per cent are some of the most striking features of permafrost areas. They can form laterally extensive exposures of ice in coastal outcrops or riverbanks

* Correspondence to: Michael Fritz, Alfred Wegener Institute for Polar and Marine Research, Telegrafenberg A43, 14473 Potsdam, Germany. E-mail: Michael.Fritz@awi.de

Contract/grant sponsor: Yukon Territorial Government.

Contract/grant sponsor: Yukon Parks (Herschel Island Qiqiktaruk Territorial Park).

Contract/grant sponsor: Yukon Department of Renewable Resources. Contract/grant sponsor: Polar Continental Shelf Programme.

Contract/grant sponsor: Aurora Research Institute.

Contract/grant sponsor: German Science Foundation (DFG).

contract/grant number: LA 2399/3-1.

Contract/grant sponsor: German Federal Ministry of Education and Research (BMBF).

contract/grant number: CAN 08/A07.

contract/grant number: CAN 09/001.

Contract/grant sponsor: German Federal Environmental Foundation (DBU).

Copyright (C) 2011 John Wiley \& Sons, Ltd. and are associated with thermokarst processes. Both the spatial distribution and origin of massive ground ice have long been investigated and debated. Many massive ice exposures are within the limits of Pleistocene glaciations of the Laurentide and the Eurasian Ice Sheets. In the late 1800s, explorers speculated that these ice bodies consisted of relict glacier ice (von Toll, 1897). However, the most commonly accepted theory in North America is that these tabular ice bodies consist of segregated or segregated-intrusive ice, and that glacial melt supplied the large volumes of water required for their formation (Mackay, 1971; Rampton, 1988; French and Harry, 1990).

Segregated and glacier ice in the modern environment can be mutually distinguished on the basis of diagnostic criteria such as crystallography and stable water isotope geochemistry, hydrochemistry, and the nature of the contacts between the ice body and the surrounding sediments (Mackay, 1989; French, 1998; Cardyn et al., 2007). However, bodies of massive ground ice have often undergone postburial hydrochemical and cryostructural alteration, as well as deformation, making interpretation a challenge (French and Harry, 1990). In the western Canadian Arctic, French and Harry (1990) and Pollard (1990) suggested that massive ice resulting from segregation Received 16 March 2010 Revised 5 January 2011 Accepted 5 January 2011 
or intrusion (or a mixture of both processes) and buried glacier ice can exist in close proximity to one another and are difficult to differentiate with only field criteria and stratigraphic appraisals. In reality, no single method can be used to assess the origin of massive ground ice with certainty; and recent studies have involved a multiple analytical methods (e.g. Lacelle et al., 2004, 2007, 2009).

Many previous investigations using the isotopic composition of ground ice to infer its origin have been based on $\delta^{18} \mathrm{O}$ data only (Lorrain and Demeur, 1985; Vasil'chuk and Vasil'chuk, 1997; Brezgunov et al., 2001) and there is a paucity of studies which have analysed both stable water isotope and hydrochemical properties (e.g. Mackay and Dallimore, 1992). Simultaneous examinations of $\delta^{18} \mathrm{O}, \delta \mathrm{D}$ and hydrochemical properties allow more detailed information to be obtained on the water source and the secondary processes affecting the build-up of ground ice (Meyer et al., 2002).

In this study, we look at two massive ground ice bodies sampled during joint Canadian-German expeditions in 2006, 2008 and 2009 to Herschel Island in the northern part of the Yukon Territory. We use $\delta^{18} \mathrm{O}, \delta \mathrm{D}$ and hydrochemical analyses to investigate these ice bodies with the goals of determining the different processes that led to their formation and identifying their water sources.

\section{STUDY SITE}

Herschel Island (69 $\left.36^{\prime} \mathrm{N}, 1^{\circ} 9^{\circ} 04^{\prime} \mathrm{W}\right)$, also known as Qikiqtaruk, is located offshore of the Yukon Coastal Plain in the southern Beaufort Sea, about $100 \mathrm{~km}$ west of the Mackenzie Delta. The island has a surface area of about 108 $\mathrm{km}^{2}$ with maximum dimensions of 8 by $15 \mathrm{~km}$ and a maximum elevation of $185 \mathrm{~m}$ above sea level (asl). Herschel Island is an ice-thrust moraine resulting from a push of the Laurentide Ice Sheet (LIS) during the Wisconsinan glaciation (Mackay, 1959). The LIS advanced at least twice along the Yukon Coastal Plain (Mackay, 1972; Duk-Rodkin et al., 2004). Rampton (1982) postulated that only the oldest advance (termed the Buckland Glaciation) reached Herschel Island during the Early to Middle Wisconsinan. However, there exists some debate regarding the timing of the LIS advance.

Permafrost thicknesses can be more than $600 \mathrm{~m}$ along the Yukon Coastal Plain (Smith and Burgess, 2000). Large areas of the coastline along Herschel Island are dominated by steep cliffs/bluffs up to an elevation of $50 \mathrm{~m}$, fronted in places by very narrow beaches. Coastal slopes are subject to intense thermokarst activity including the development of retrogressive thaw slumps (Lantuit and Pollard, 2008). The presence of numerous thaw slumps along the coast is an indicator that massive ground ice bodies underlie most of the island, and may constitute up to 50 per cent of the volume of the near-surface permafrost (Mackay, 1971).

The massive ground ice bodies studied are at opposite ends of the island (Figure 1). The first is in the southeast at $69^{\circ} 35^{\prime} 52.1^{\prime \prime} \mathrm{N}, 139^{\circ} 13^{\prime} 56.8^{\prime \prime} \mathrm{W}$, at an elevation of $50 \mathrm{~m}$ asl (Figure 2a). Here, the ground ice body is exposed within the headwall of a coastal retrogressive thaw slump called D (henceforth termed 'TSD', see Lantuit and Pollard, 2005).

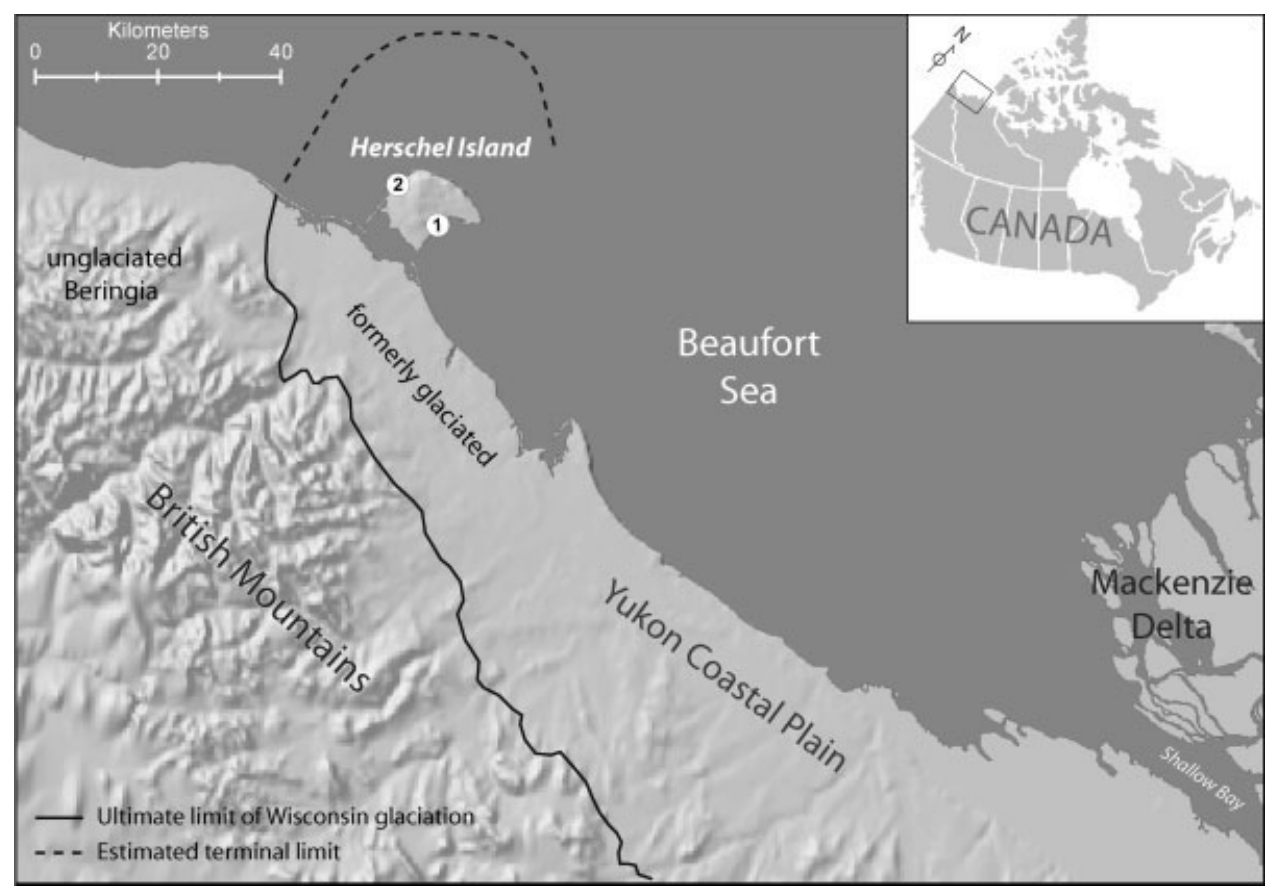

Figure 1 Location of Herschel Island and position of the two study sites: (1) thaw slump D (TSD massive ice) and (2) Herschel Island West massive ice (HIW massive ice). The limit of the Wisconsinan glaciation was redrawn according to Smith et al. (1989), and adapted from Rampton (1982) and Dyke and Prest (1987). 

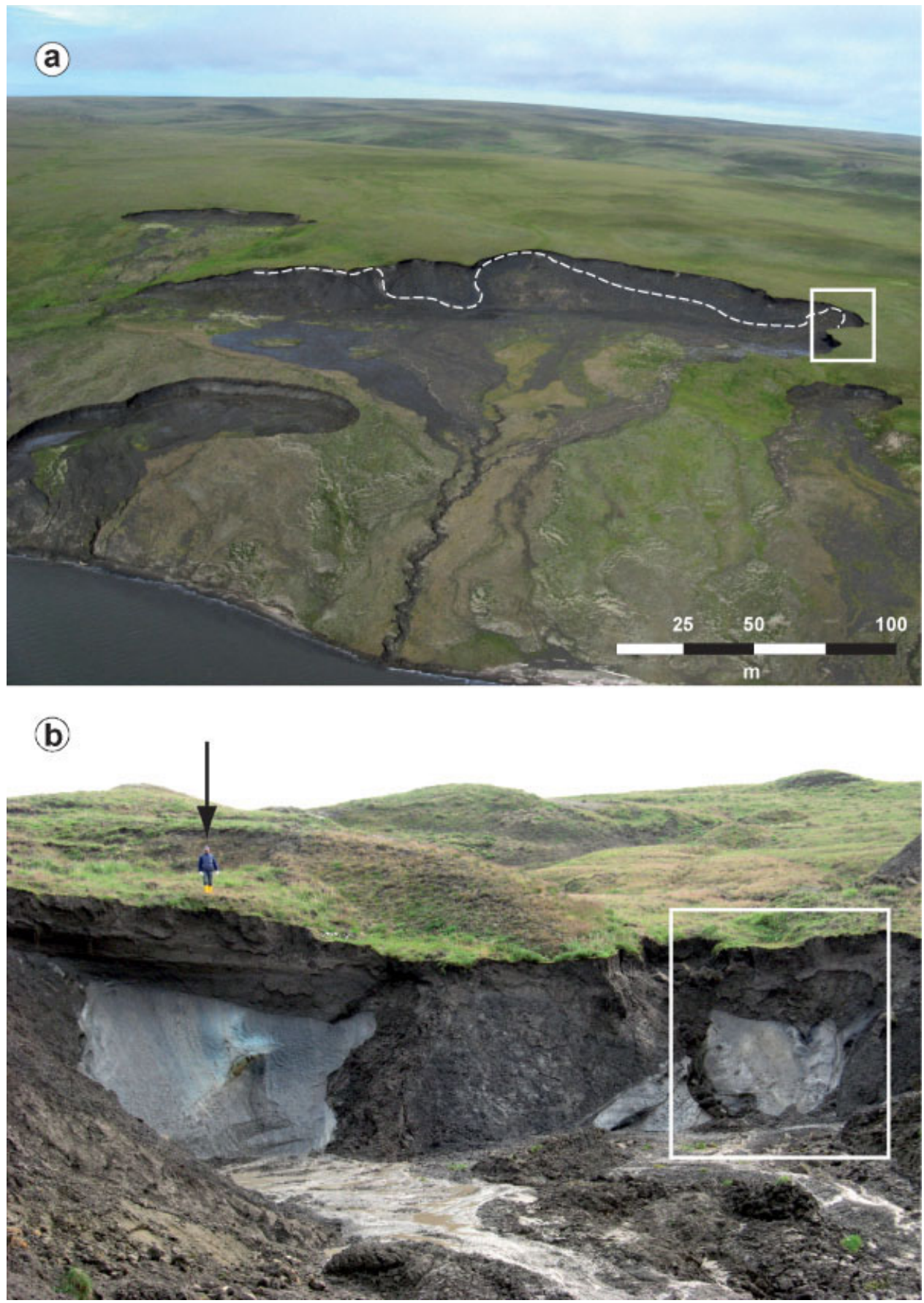

Figure 2 Overview photographs of (a) retrogressive thaw slump D (TSD) on the southeastern coast of Herschel Island and (b) Herschel Island West massive ice exposure (HIW). The dashed line delineates the orientation of the massive ice body which is non-conformable with the overlying surface. The white rectangles indicate sampling locations. Arrow points to the person standing above the HIW exposure for scale.

The second site is located along the northwest coast of the island $\left(69^{\circ} 38^{\prime} 27.9^{\prime \prime} \mathrm{N}, 139^{\circ} 05^{\prime} 41.0^{\prime \prime} \mathrm{W}\right.$ at approximately $20 \mathrm{~m}$ asl) where an exposure adjacent to an eroding valley revealed a large heterogeneous body of massive ground ice (Figure 2b). This site is referred to as HIW massive ice (Herschel Island west).

\section{MATERIAL AND METHODS}

Samples were obtained from the TSD and HIW massive ice sites and from non-massive intrasedimental ice at TSD. The vertical profile heights of the exposed sections were measured with a tape measure and the headwall was cleaned of thawed 
material. A detailed description and characterisation of each profile provided an overview of sedimentary and cryolithological features and their stratigraphic relationships. A chain saw and ice screws were used to cut transects across the exposed massive ice. The outer layer of the ice samples was discarded to avoid contamination by surface runoff. A total of 50 ground ice samples were collected from the TSD exposure and 91 samples from the HIW exposure.

\section{Stable Water Isotope Geochemistry}

The samples were analysed for stable water isotopes $\left(\delta^{18} \mathrm{O}, \delta \mathrm{D}\right)$ and hydrochemistry at the Alfred Wegener Institute for Polar and Marine Research (Potsdam, Germany). Ice samples were thawed in the field and kept cool within narrow-mouth PE bottles until they were analysed. We measured the electrical conductivity (EC) directly in the field on the melted samples using a handheld multi-parameter instrument (WTW 340i, Tetracon 325, Weilheim, Germany).

Stable water isotope analyses were carried out with a mass spectrometer (Finnigan MAT Delta-S, Bremen, Germany) using the water-gas equilibration technique (for further information see Horita et al., 1989). The isotopic composition is expressed in delta per mil notation $(\delta, \%)$ relative to the Vienna Standard Mean Ocean Water (VSMOW) standard. The reproducibility derived from long-term standard measurements is established with $1 \sigma$ better than $\pm 0.1 \%$ or for $\delta^{18} \mathrm{O}$ and $0.8 \%$ for $\delta \mathrm{D}$ (Meyer et al., 2000).

\section{Hydrochemistry}

A representative selection of the ice samples used for the determination of stable isotope ratios was split for hydrochemical measurements ( $c a$. every second sample). Samples for ion analysis were passed through celluloseacetate filters (pore size $0.45 \mu \mathrm{m}$ ) in the field. Samples for cation analyses were acidified with $\mathrm{HNO}_{3}$ to prevent microbial conversion processes, whereas samples for anion analysis were kept cool. The cation content was analysed by inductively coupled plasma-optical emission spectrometry (Perkin-Elmer Optima 3000 XL, Waltham, Massachusetts, USA), while the anion content was determined by ion chromatography (Dionex DX-320, Sunnyvale, California, USA). Hydrogen carbonate concentrations were determined by titration with $0.01 \mathrm{M} \mathrm{HCl}$ using an automatic titrator (Metrohm 794 Basic Titrino, Filderstadt, Germany).

The detection limits for the different ions are $0.1 \mathrm{mg} / \mathrm{l}$ for $\mathrm{Cl}^{-}, \mathrm{SO}_{4}^{2-}, \mathrm{Ca}^{2+}$ and $\mathrm{Mg}^{2+}, 0.2 \mathrm{mg} / \mathrm{l}$ for $\mathrm{K}^{+}$and $\mathrm{Na}^{+}$and $3.05 \mathrm{mg} / \mathrm{l}$ for $\mathrm{HCO}_{3}^{-}$. A standard error of \pm 10 per cent is taken for all values.

\section{RESULTS}

\section{TSD exposure}

\section{Stratigraphy.}

This retrogressive thaw slump is more than $400 \mathrm{~m}$ wide, features a vertical headwall up to $10 \mathrm{~m}$ high and a more gently sloping headscarp $15-20 \mathrm{~m}$ in height where the massive ice body is exposed (Figure 2a). The massive ice can be traced laterally across the headwall by an undulating milky white ice band (Figure 2a) and exhibits synclinal and anticlinal structures (Figure 3c), while it appears domeshaped further north (Figure 3b). A generalised stratigraphy of the exposure is shown in Figure $3 a$.

Unit A of TSD (Figure 3) is a massive ice body of almost pure ice with a thickness of more than $10 \mathrm{~m}$. It is mainly composed of clear to milky white ice. Sediments are present in a dispersed form and as sediment bands with a variable frequency and a thickness of $5 \mathrm{~mm}$ to several centimetres. Layers of a matrix-based diamicton (with occasional cobbles) are deformed together with the ice, leading to anticlinal and synclinal as well as vertically and horizontally bedded structures (Figure $3 \mathrm{~b}$ and c). These gentle folds are open and either upright or inclined. Subangular rounded cobbles (diameters up to $5 \mathrm{~cm}$ ) are incorporated into the ice. Gas bubbles are up to $5 \mathrm{~mm}$ in diameter and are not oriented within the ice, in contrast to the sediment inclusions that are elongated and oriented in the same direction as the inclination of folds. The lower contact of the massive ice was not exposed. The upper contact of the massive ice is unconformable. In some parts of the exposure, the massive ice is unconformably overlain by an ice-rich clayey diamicton (unit B, Figure 3a) with an alternating texture of thick ice lenses $(2-20 \mathrm{~cm})$ and sediments. Samples of nonmassive intrasedimental ice were taken from this unit. Subangular rounded pebbles, cobbles and the remains of molluscs as well as dispersed plant remains are present throughout the unit. In some places the overlying ice-rich sediments exhibit deformation structures, such as recumbent isoclinal folds and boudinage structures, indicative of a strong linear shear stress and plastic deformation of a competent material. The upper contact of unit B has been discordantly truncated towards unit $\mathrm{C}$, as indicated by cut cryostructures and truncated tails of ice wedges that penetrate into the diamictic sediments and the deformation structures of unit B.

Unit $\mathrm{C}$ comprises a greyish-brown diamicton up to $3 \mathrm{~m}$ thick (Figure 3a). It is less ice-rich and characterised by a lens-like reticulate to irregular reticulate cryostructure without deformation structures. The sediment texture of unit $\mathrm{C}$ is comparable to that of unit $\mathrm{B}$ but has a higher content of organic remains and exhibits some peat inclusions.

Unit D (Figure 3a) is present in the former depressions of a polygonised tundra and represents the infill of low-centre ice-wedge polygons during stable surface conditions. Peat is up to $2.5 \mathrm{~m}$ thick, while relict ice wedges up to $3 \mathrm{~m}$ wide and up to $5 \mathrm{~m}$ long penetrate downwards through units $\mathrm{B}$ and $\mathrm{C}$ and sometimes also into the massive ice (Figure $3 \mathrm{a}$ ).

\section{Stable Water Isotopes.}

The stable water isotope composition of massive ground ice (unit A) exposed in TSD has $\delta^{18} \mathrm{O}$ values ranging from -34.2 to $-31.3 \%$ and $\delta \mathrm{D}$ values from -265 to $-244 \%$ (Figure 4; Table 1). With an average deuterium excess of $7.2 \%$ and a $\delta \mathrm{D}-\delta{ }^{18} \mathrm{O}$ regression slope value of 

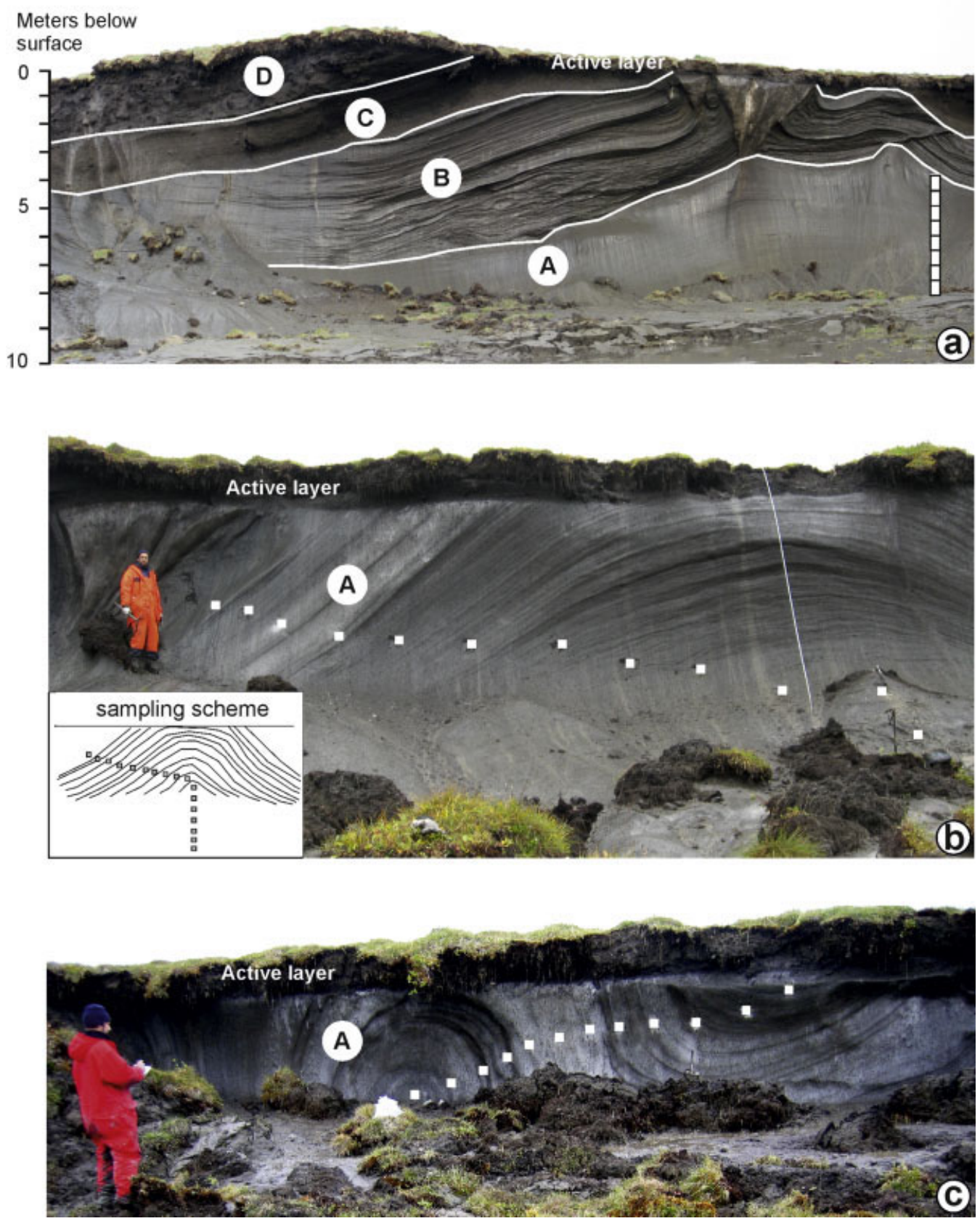

Figure 3 Stratigraphic units (A to D) and sampling points (white squares) of thaw slump D massive ice (unit A) in 2006, 2008 and 2009. (a) shows a generalised stratigraphy of the exposure, (b) illustrates the dome-shaped nature of the ice body, and (c) shows its synclinal and anticlinal structures. Unit A: massive ice body with sediment bands that are deformed together with the ice; unit B: clayey diamicton with an alternating pattern of thick ice lenses $(2-20 \mathrm{~cm})$; unit C: clayey diamicton with a lens-like reticulate to irregular reticulate cryostructure; unit D: peaty silt with lens-like reticulate cryostructure and inactive ice wedges. Note the persons standing in front of the exposure for scale.

$7.0\left(\mathrm{R}^{2}=0.98\right)$, samples from the massive ice body lie slightly below the global meteoric water line (GMWL, $\delta \mathrm{D}=8 \delta^{18} \mathrm{O}+10$; Craig, 1961). Values for $d$ vary from 5.3 to $9.3 \%$. Neither the isotopic signature nor the deuterium excess exhibits any spatial trend across the profiles through the ice body.
Intrasedimental ice within unit B shows higher isotopic values ranging from $-28.7 \%$ to $-25.8 \%$ for $\delta^{18} \mathrm{O}$ (Figure 4 ; Table 1), indicating fractionation processes during multiple freeze-thaw cycles in an active layer before permafrost aggradation, or mixed water sources, or that it formed under warmer climate conditions. The deuterium excess of the 


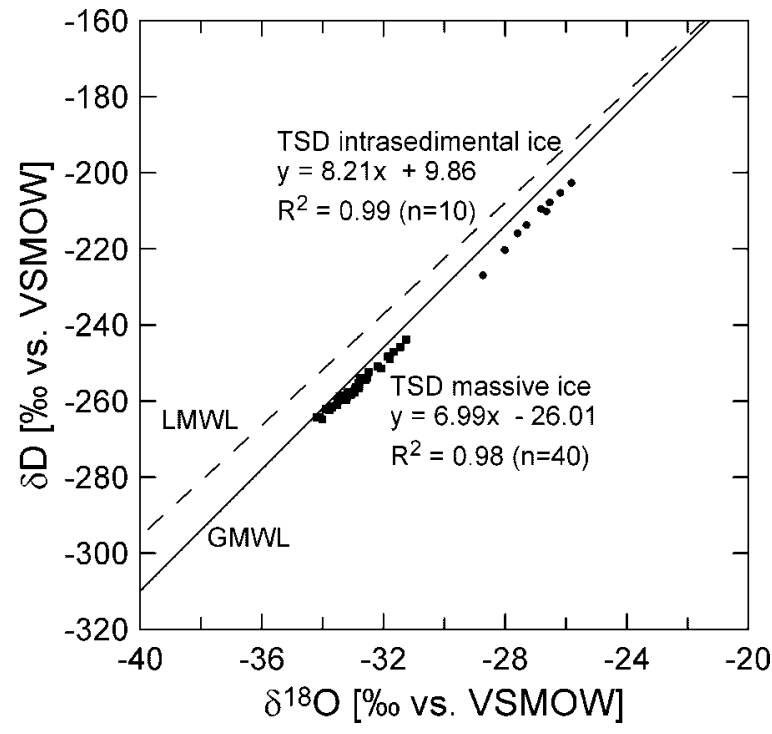

Figure $4 \quad \delta^{18} \mathrm{O}-\delta \mathrm{D}$ diagram of thaw slump D (TSD) massive ice (unit A, squares) and TSD non-massive intrasedimental ice of adjacent sediments (unit B, dots). GMWL $=$ global meteoric water line; $\mathrm{LMWL}=$ local meteoric water line for Inuvik (IAEA, 2006): $\delta \mathrm{D}=7.3 \delta^{18} \mathrm{O}-3.5, \mathrm{R}^{2}=0.98$; VSMOW $=$ Vienna Standard Mean Ocean Water.

intrasedimental ice samples ranges between 3.0 and 5.1\%o without showing any trend with depth. The isotopic composition of intrasedimental ice in unit $\mathrm{B}$ overlying the massive ice is dissimilar to that of the massive ice in unit A, indicating differing conditions during the formation of the two ice types (Figure 4; Table 1).

\section{Hydrochemical Composition.}

The EC of the melted ice samples shows a wide range, from 20.6 to $1294 \mu \mathrm{S} / \mathrm{cm}$ (mean: $406 \mu \mathrm{S} / \mathrm{cm}$; Table 2). Higher EC values accompany higher sediment contents and we therefore assume in-situ ion-exchange processes between the sediment particles and the ice. However, we cannot eliminate the possibility that further dissolution of soluble salts from enclosing sediments occurred after thawing of the samples, so interpretations of the hydrochemical results are tentative.

The entire massive ice body is dominated by $\mathrm{HCO}_{3}^{-}$for the anion composition (53\%) followed by $\mathrm{Cl}^{-}$and $\mathrm{SO}_{4}^{2-}$ (Figure 5). Cation concentrations are dominated by $\mathrm{Na}^{+}$,
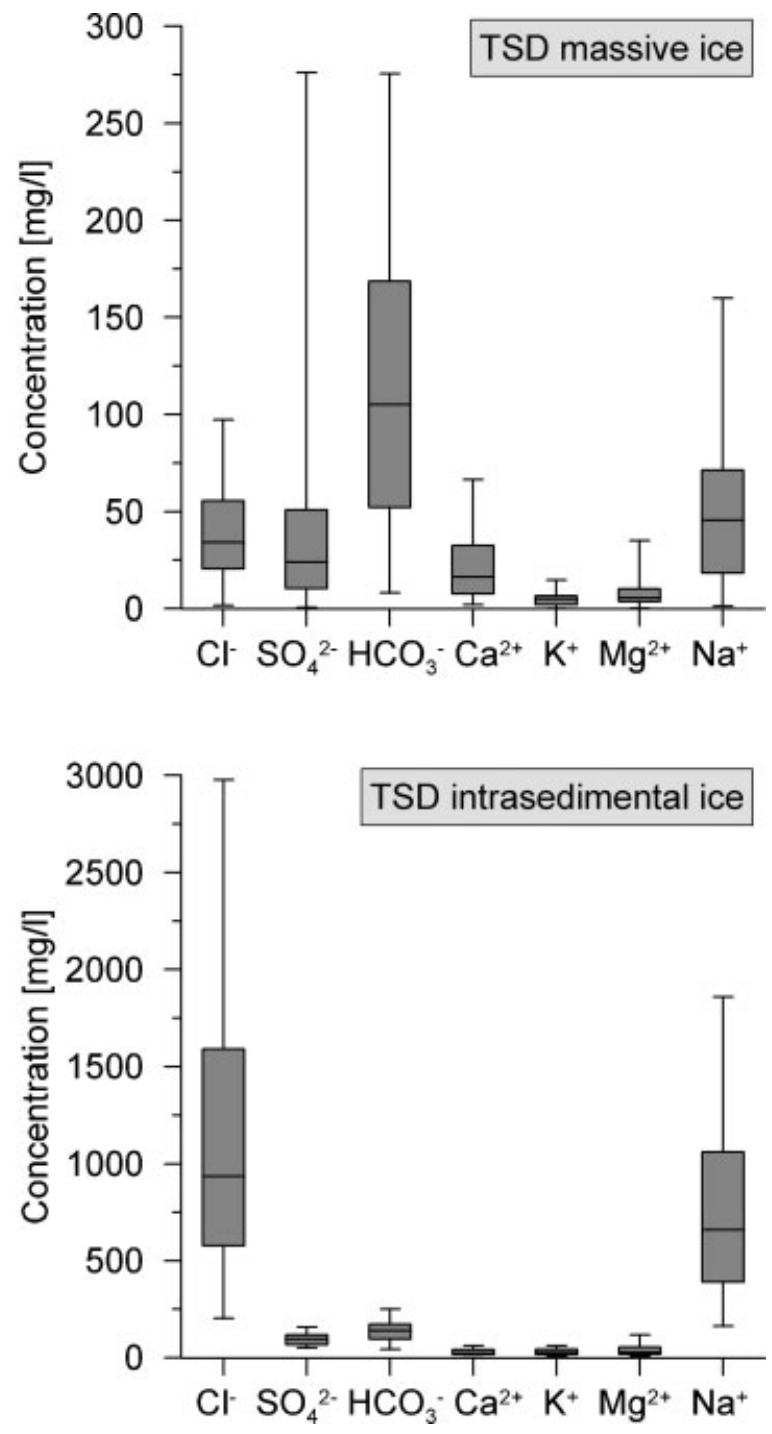

Figure 5 Boxplots of cation and anion concentrations (absolute values in $\mathrm{mg} / \mathrm{l}$ ) of thaw slump D (TSD) massive ice and TSD non-massive intrasedimental ice of surrounding sediments. Note the different scales for ion concentrations of TSD massive and intrasedimental ice. Plots show the minimum, maximum, median, 25 per cent quartile and 75 per cent quartile.

Table 1 Stable isotope $\left(\delta^{18} \mathrm{O}, \delta \mathrm{D}\right.$ and $\left.d\right)$ minimum, mean and maximum values, as well as slopes and linear regression coefficients of the $\delta \mathrm{D}-\delta^{18} \mathrm{O}$ relation for the different ice types sampled.

\begin{tabular}{|c|c|c|c|c|c|c|c|c|c|c|c|c|}
\hline \multirow[t]{2}{*}{ Profile } & \multirow[t]{2}{*}{$\mathrm{N}$} & \multicolumn{3}{|c|}{$\delta^{18} \mathrm{O}$} & \multicolumn{3}{|c|}{$\delta \mathrm{D}$} & \multicolumn{3}{|c|}{$d$} & \multirow[t]{2}{*}{ Slope } & \multirow[t]{2}{*}{$\mathrm{R}^{2}$} \\
\hline & & Min. & Mean & Max. & Min. & Mean & Max. & Min. & Mean & Max. & & \\
\hline TSD massive ice & 40 & -34.2 & -33.0 & -31.3 & -265 & -258 & -244 & 5.3 & 7.2 & 9.3 & 7.0 & 0.98 \\
\hline TSD intrasedimental ice & 10 & -28.7 & -27.2 & -25.8 & -227 & -213 & -203 & 3.0 & 4.2 & 5.1 & 8.2 & 0.99 \\
\hline HIW massive ice & 91 & -39.0 & -31.2 & -21.0 & -286 & -237 & -169 & -3.9 & 6.9 & 25.3 & 5.9 & 0.99 \\
\hline
\end{tabular}

$\mathrm{TSD}=$ Thaw slump D; HIW = Herschel Island West. 
Table 2 Summarised values of two major ion ratios for the different profiles and ice types.

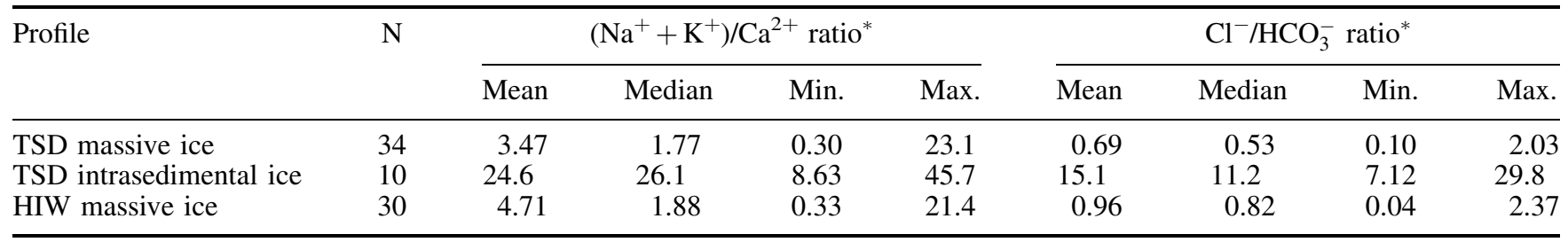

Note: $\left(\mathrm{Na}^{+}+\mathrm{K}^{+}\right) / \mathrm{Ca}^{2+}$ and $\mathrm{Cl}^{-} / \mathrm{HCO}_{3}^{-}$ratios greater than unity indicate an enrichment of ions with a likely marine origin derived from salt spray or dissolution from sediments with a marine influence. TSD = Thaw slump D; HIW = Herschel Island West.

accounting for $50 \%$, followed by $\mathrm{Ca}^{2+}, \mathrm{Mg}^{2+}$ and $\mathrm{K}^{+}$ (Figure 5). No vertical or horizontal trend in the major ion distribution is apparent.

The hydrochemical properties of intrasedimental ice within the overlying sediments (unit B) differ significantly from the massive ice body directly below (unit A). The EC of intrasedimental ice averages $3957 \mu \mathrm{S} / \mathrm{cm}$ with maximum values above $5500 \mu \mathrm{S} / \mathrm{cm}$. Na ${ }^{+}$and $\mathrm{Cl}^{-}$ions are dominant (Figure 5), representing more than $84 \%$ of the total ion composition. $\mathrm{NaCl}$ waters clearly reflect a marine signature and therefore indicate a strong ion-exchange process between porewater and the solute-rich diamicton in which the segregated ice formed.

\section{HIW exposure}

\section{Stratigraphy.}

The HIW massive ice body measures between 4 and $8 \mathrm{~m}$ high, is unconformably overlain by several metres of sediments and shows a sharp boundary (i.e. no sediment incorporation into melted margins) between massive ice and sediments (Figure 6 ). To the east, the ice is overlain by $\sim 6 \mathrm{~m}$ of dark grey clay (unit B), itself covered by brownish-grey fine-grained deposits with a significant content of plant macrofossils (unit $\mathrm{C}$ ). The cryostructure of units $\mathrm{B}$ and $\mathrm{C}$ is coarse lens-like reticulate with ice lenses $0.5-1 \mathrm{~cm}$ thick, likely indicating re-freezing after deposition. The clayey sediments are generally ice-poor with cobbles and plant remains. A notable feature is the occurrence of large, striated boulders more than $1 \mathrm{~m}$ in diameter at the mouth of a narrow valley located $10 \mathrm{~m}$ further west at approximately the same elevation as the massive ice body.

The HIW ice body is not homogeneous. Its different parts have distinctive cryolithological characteristics (Figure 6). The outer part of the HIW ice body (A-1, Figure 6), which makes up the largest portion, consists of very clear ice with few gas bubble inclusions and without any sediment inclusions. The central part of the ice body is composed of milky white ice (A-2, Figure 6) with sometimes finedispersed sediment inclusions and an apparently high gas content. Spherical gas bubbles are up to $4 \mathrm{~mm}$ in diameter, not oriented and occur either dispersed or in clusters. The uppermost part of HIW (A-3, Figure 6) is regarded as a transition zone between part A-1 and A-2. It has few sediment and gas inclusions and a bluish-cloudy appearance.
Stable Water Isotopes.

Although one compact ice body was encountered, the $\delta \mathrm{D}$ and $\delta{ }^{18} \mathrm{O}$ composition varies from -39.0 to $-21.0 \%$ for $\delta^{18} \mathrm{O}$ and from -286 to $-169 \%$ for $\delta \mathrm{D}$ (Figure 7 ; Table 1 ). The deuterium excess also ranges widely, between -3.9 to $25.3 \%$ (mean of $6.9 \%$ ). The $\delta^{18} \mathrm{O}$ values show a decreasing trend from -21.0 to $-39.0 \%$ towards the centre of the ice body, whereas $d$ values increase towards the centre. In its interior, $\delta^{18} \mathrm{O}$ is generally less than $-33.0 \%$ down to its minimum of $-39.0 \%$ (Figure 7 ; Table 1 ). The very clear ice forming the outer parts of the ice body close to the sediment contact shows negative $d$ values slowly increasing inwards. The $\delta \mathrm{D}-\delta^{18} \mathrm{O}$ regression slope of 5.9 (Figure 7) is lower than the slope typically assumed for water or ground ice from meteoric sources that has not undergone secondary fractionation.

\section{Hydrochemical Composition.}

The total ion content of the ice is generally low with EC values of $212 \mu \mathrm{S} / \mathrm{cm}$ on average. The massive ice body is generally dominated by $\mathrm{HCO}_{3}^{-}(55 \%)$ and $\mathrm{Cl}^{-}(37 \%)$ for the anion composition with absolute contents usually less than $40 \mathrm{mg} / \mathrm{l}$ each (Figure 8). The cation composition is dominated by $\mathrm{Na}^{+}$, accounting for $58 \%$ and followed by $\mathrm{Ca}^{2+}$ with $30 \%$ on average. Hydrochemical studies of this ice body show the same continuous trend in ion concentration from the ice margins towards the centre observed for $\delta^{18} \mathrm{O}$ and $\delta \mathrm{D}$. The very clear and transparent ice comprising the outer parts of the massive ice body (A-1 in Figure 6) has the lowest ion content. As one moves further into the centre of the ice body, EC rises gradually (up to $1000 \mu \mathrm{S} / \mathrm{cm}$ ) and so does the ion content. The milky white central part of the ice exhibits comparably high values of $\mathrm{Cl}^{-}(207 \mathrm{mg} / \mathrm{l}), \mathrm{HCO}_{3}^{-}(164 \mathrm{mg} / \mathrm{l})$ and $\mathrm{Na}^{+}(188 \mathrm{mg} / \mathrm{l})$ (Figure 8).

\section{DISCUSSION}

\section{Origin of TSD Massive Ice (Unit A)}

The negative $\delta^{18} \mathrm{O}$ isotopic composition of the TSD massive ice $\left(\delta^{18} \mathrm{O}\right.$ between -34 and $-31 \%$ ) indicates that the water contributing to ice formation originated in a cold environment, likely during the Wisconsinan under full- 

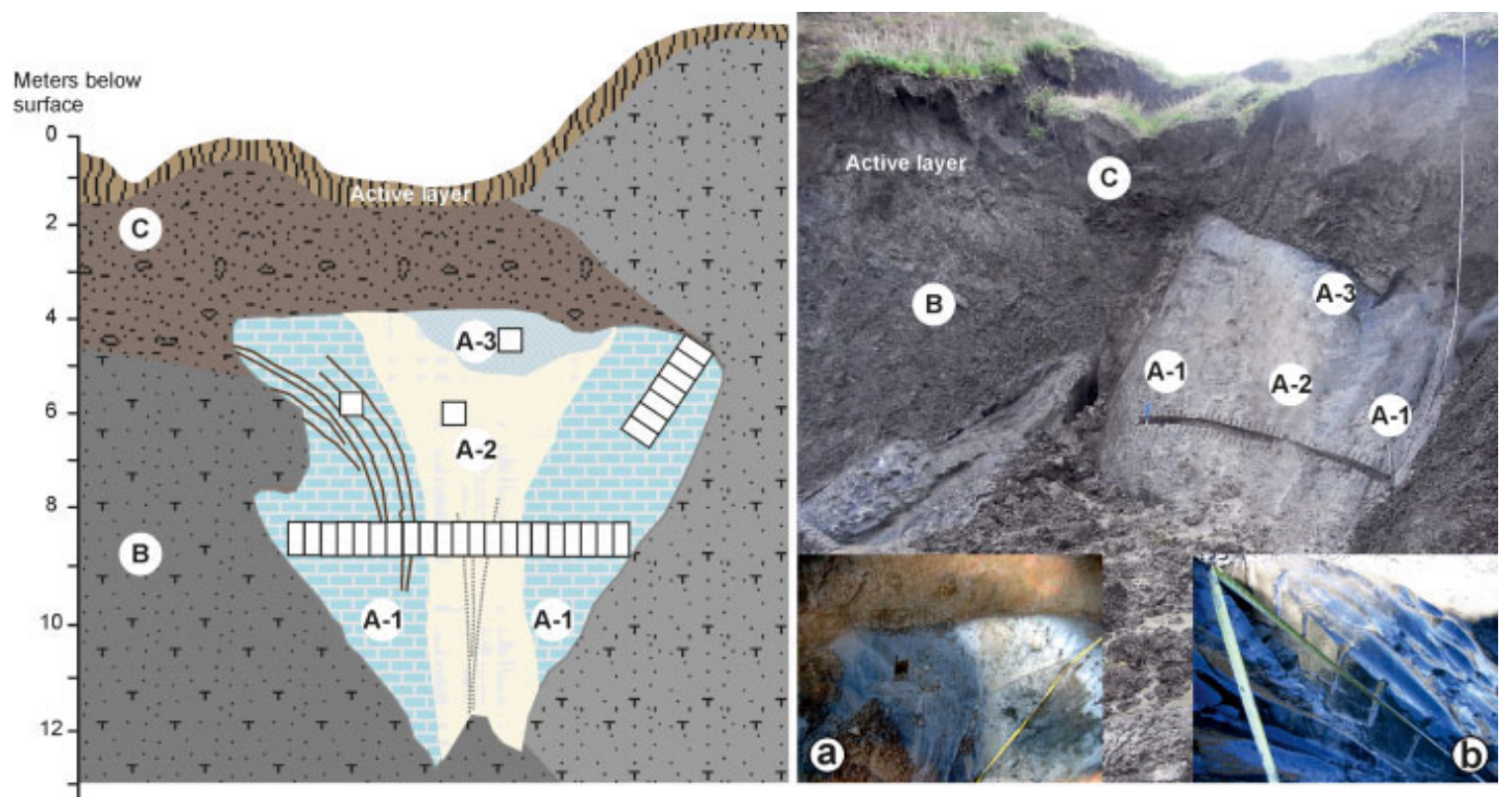

Figure 6 Stratigraphic units (A to C) and sampling points (white squares) of Herschel Island West massive ice (unit A). Unit A-1: transparent ice without bubbles and without sediment inclusions; unit A-2: milky white ice, bubble-rich; unit A-3: transition zone between A-1 and A-2 with bluish cloudy appearance, few sediment inclusion and bubbles; unit B: dark grey clay; unit C: brownish-grey, fine-grained sediments with plant remains and peaty inclusions. Inset (a) illustrates the sharp transition between transparent (unit A-1) to milky white ice (unit A-2). Inset (b) shows the very clean and transparent character of unit A-1 ice.

glacial conditions. Similar isotopic ratios have been determined for possible Late Pleistocene massive ground ice (e.g. Michel and Fritz, 1978, 1983; Mackay, 1983; Moorman et al., 1998), non-massive intrasedimental ice (Kotler and Burn, 2000) and remnants of Pleistocene glacier

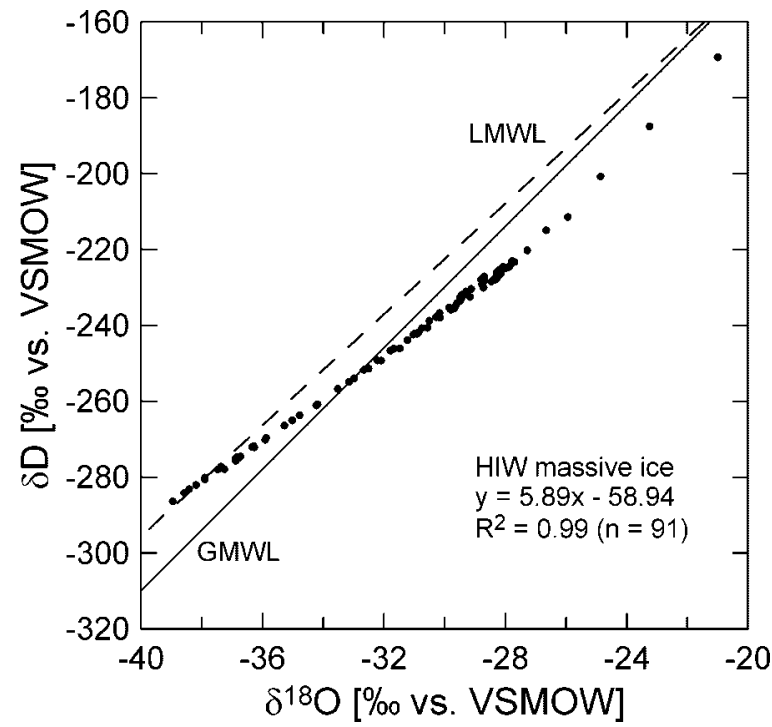

Figure $7 \quad \delta^{18} \mathrm{O}-\delta \mathrm{D}$ diagram of Herschel Island West (HIW) massive ice. $\mathrm{GMWL}=$ global meteoric water line; $\mathrm{LMWL}=$ local meteoric water line for Inuvik (IAEA, 2006): $\delta \mathrm{D}=7.3 \quad \delta^{18} \mathrm{O} \quad-3.5, \quad \mathrm{R}^{2}=0.98$; VSMOW $=$ Vienna Standard Mean Ocean Water. ice or basal regelation ice (Dansgaard and Tauber, 1969; Hooke and Clausen, 1982; Lorrain and Demeur, 1985; Zdanowicz et al., 2002). We assume a single water and/or moisture source, because of the narrow isotopic range, that may have been derived from glacier ice or glacial meltwater

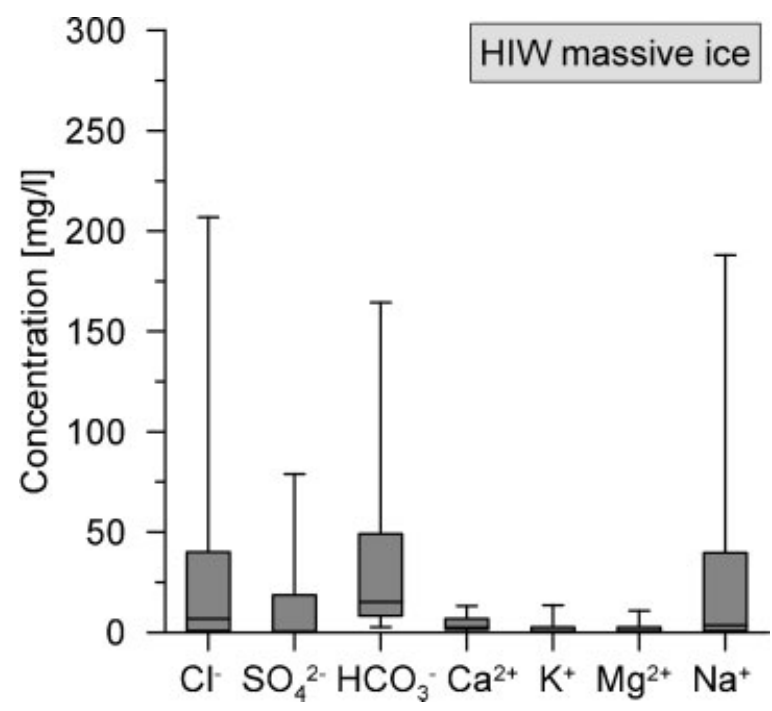

Figure 8 Boxplot of cation and anion concentrations (absolute values in $\mathrm{mg} / \mathrm{l}$ ) of Herschel Island West (HIW) massive ice. Plots show the minimum, maximum, median, 25 per cent quartile and 75 per cent quartile. 
(Rampton, 1988, 2001; French and Harry, 1990) with a strongly depleted isotopic signature.

The $\delta \mathrm{D}-\delta^{18} \mathrm{O}$ regression slope of 7.0 is somewhat lower than that of the GMWL $(S=8)$ but in close agreement with the slope of the closest modern local meteoric water line (LMWL) for Inuvik, about $200 \mathrm{~km}$ east of Herschel Island. However, a slope of 7.0 does not necessarily point to a meteoric origin but could account for freezing of liquid water as well. During equilibrium freezing, the value of the $\delta \mathrm{D}-\delta{ }^{18} \mathrm{O}$ regression slope differs from that of the GMWL because of different isotopic fractionation coefficients (for D and ${ }^{18} \mathrm{O}$ ) during the water-ice-phase change than it is the case for the water-vapour fractionation. Using the fractionation coefficients for the ice-water-phase change by Suzuoki and Kimura (1973) of $\alpha\left(\mathrm{D}_{\mathrm{i}-\mathrm{w}}\right)=1.0206$ and $\alpha\left({ }^{18} \mathrm{O}_{\mathrm{i}-}\right.$ w) $=1.0028$, the theoretical freezing slope becomes 7.3. Consequently, ice derived from equilibrium freezing should plot along a regression slope below or equal to the theoretical freezing slope.

The deuterium-excess analyses of the massive ice body do not provide conclusive evidence. An average $d$ value of $7.2 \%$ plots well below the GMWL $(d=10)$ and the LMWL $(d=14.9)$, respectively (Figure 9). There is no strong negative relation between $d$ and $\delta \mathrm{D}$ which would suggest the existence of a freezing slope. However, this could mean that freezing occurred under non-equilibrium conditions. Frequent regelation, adfreezing and sediment incorporation at the glacier sole could cause mixing with groundwater and kinetic fractionation as well (Souchez et al., 1990, 2000).

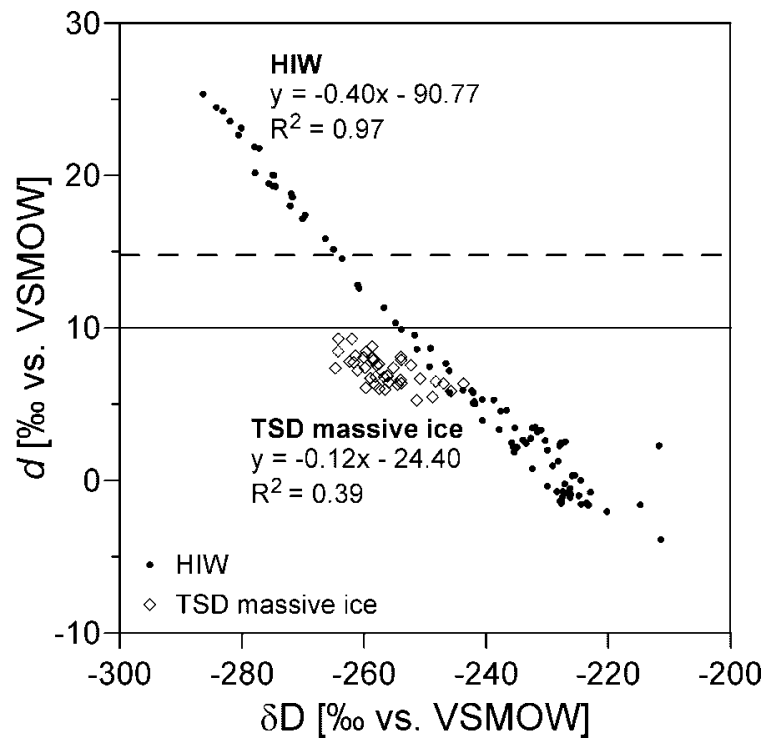

Figure 9 Relationship between $\delta \mathrm{D}$ and deuterium excess $(d)$ of the two massive ice types: thaw slump D (TSD) and Herschel Island West (HIW). The horizontal solid line represents $d$ of the global meteoric water line $(d=10)$. The dashed line shows the $d$ value of the local meteoric water line for Inuvik $(d=14.9$; IAEA, 2006). VSMOW = Vienna Standard Mean Ocean Water.
The hydrochemistry of basal regelation ice can be strongly affected by interactions between water, ice, and solutes from basal and englacial debris (Knight, 1997). Given the assumption that the enclosed sediments have been incorporated by some freezing process of liquid water, a solution equilibrium between water and sediment may have been established prior to freezing. Artificial thaw for analysis could change this equilibrium, but should not completely change the ion composition as the artificial meltwater is the same water that formed the ice. Regelation ice with prolonged contact with the surrounding sediments would lose its hydrochemical purity due to ion-exchange processes and the tendency to balance differences in concentration. Incorporated debris would leave its hydrochemical imprint on the ice. On Herschel Island, glacially upthrust near-shore marine deposits (Mackay, 1959; Bouchard, 1974) containing both marine and terrestrial fossils are presumed to be the major ion source for any kind of ground ice that had contact with them in a liquid or frozen state. A recharge of groundwater by glacial meltwater leading to the formation of tabular massive ice bodies has been described by Moorman et al. (1998). This takes into account that the ice should reflect both the hydrochemical signature of the glacial meltwater and that of the sediments it travelled through. The ratios of $\left(\mathrm{Na}^{+}+\mathrm{K}^{+}\right) / \mathrm{Ca}^{2+}$ and $\mathrm{Cl}^{-} /$ $\mathrm{HCO}_{3}^{-}$were calculated (Table 2) including the two main ions in sea water $\mathrm{Na}^{+}$and $\mathrm{Cl}^{-}$and those typical of terrestrial waters $\left(\mathrm{HCO}_{3}^{-}, \mathrm{Ca}^{2+}\right)$. Alkali ions dominate the massive ice but to a lesser degree than is the case for the intrasedimental ice. Furthermore, $\mathrm{HCO}_{3}^{-}$is dominant in the massive ice giving a clear terrestrial signature.

Alternating layers of debris-rich ice and debris-poor but bubble-rich ice were found. These features may be ascribed to either segregation or glaciotectonic structures as observed in deformed marginal or basal glacier ice (e.g. Sugden et al., 1987; Knight, 1997; Knight et al., 2000; Murton et al., 2005). Density inversions between the more than $10 \mathrm{~m}$ of almost pure ice and the sediment cover with a higher density could lead to updoming of the underground ice in zones of weakness (Harris, 1989) over the millennia since deglaciation, resulting in the large-scale undulating and updoming patterns observed in the ice body. Gradational contacts are typical for massive segregated ice (also segregated-intrusive ice) (Mackay, 1989) but they should not exist for buried ice and in this case an unconformable upper contact was present while the lower contact was hidden. There is strong evidence that Pleistocene basal glacier (or basal regelation ice) was incorporated into glacial diamicton or became buried by supraglacial meltout till (see Murton et al., 2005). However, we cannot rule out the possibility that the ice originated as massive segregated (-intrusive) ice as both types can contain significant quantities of stratified debris (e.g. French and Harry, 1990; Knight, 1997; Knight et al., 2000; Murton et al., 2005). The question remains whether the ice body aggraded as massive segregated (-intrusive) ice and was then deformed by glaciotectonic processes, or if the ice was originally basal regelation ice forming part of the Laurentide ice lobe that became buried by a till. 


\section{Origin of HIW Massive Ice}

A large isotopic range of about $18 \%$ (for $\delta^{18} \mathrm{O}$ ) occurs within the HIW ice body together with extremely low values in its centre $(-39.0 \%)$. As far as we know, this range accompanied by the very low $\delta^{18} \mathrm{O}$ values is unique in the literature on massive ground ice. Figure 10 shows the progressive symmetrical depletion in heavy isotopes inwards towards the most negative values near the centre of the ice body and strong solute enrichment in the same direction. We infer that the ice body was formed under closed-system conditions as a result of complete freezing of a single water body with a mixed terrestrial-marine hydrochemical signature (Table 2) for the following reasons.

When water freezes under equilibrium conditions it follows Rayleigh-type fractionation between water and ice. Written in delta-notation, the Rayleigh equation becomes (Lacelle, 2011):

$\delta_{i}=\left(\delta_{0}+\operatorname{In} \alpha_{i-w} \cdot 1000 \cdot \operatorname{In} f\right)+\operatorname{In} \alpha_{i-w} \cdot 1000$

with $\delta i$ as the resulting isotope composition of the ice, $\delta_{0}$ as the initial isotope composition of the parent water and $f$ as the remaining water fraction during freezing. The first part of a water reservoir to freeze in a closed system will produce ice that is isotopically enriched by about $2.8 \%$ relative to the source water (Craig, 1961; Michel, 1986). As freezing continues, the shrinking reservoir becomes increasingly depleted in heavy isotopes (Figure 11). In contrast, dissolved

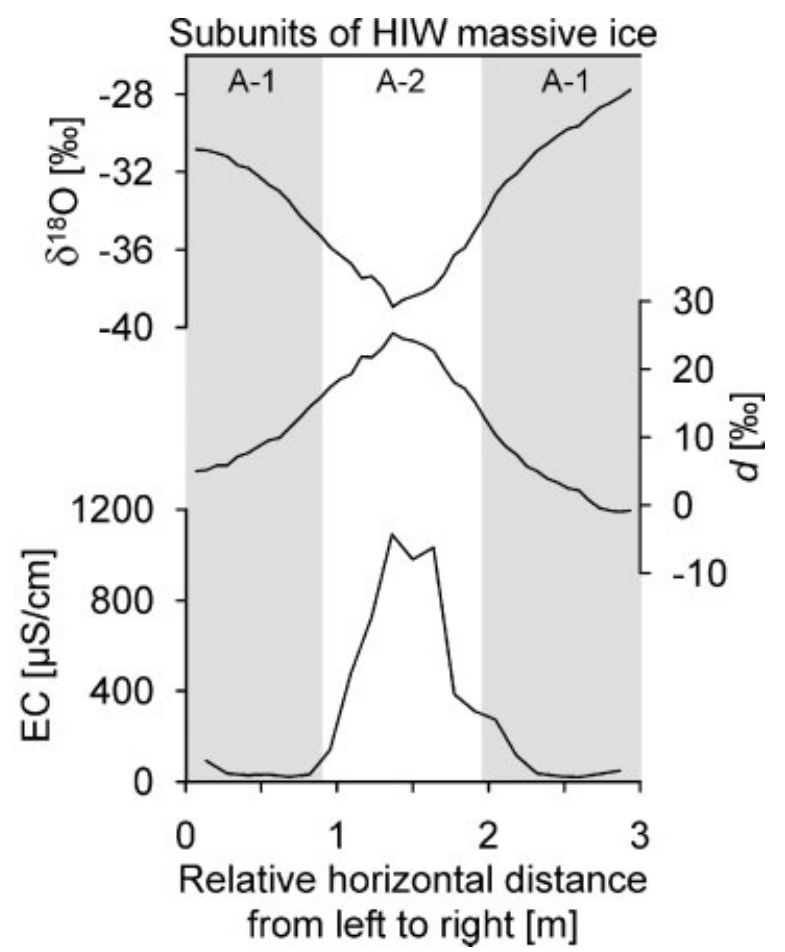

Figure $10 \quad \delta^{18} \mathrm{O}$, deuterium excess $(d)$ and total ion content (expressed as electrical conductivity, EC) across a horizontal transect in Herschel Island West (HIW) massive ice (see also Figure 7).

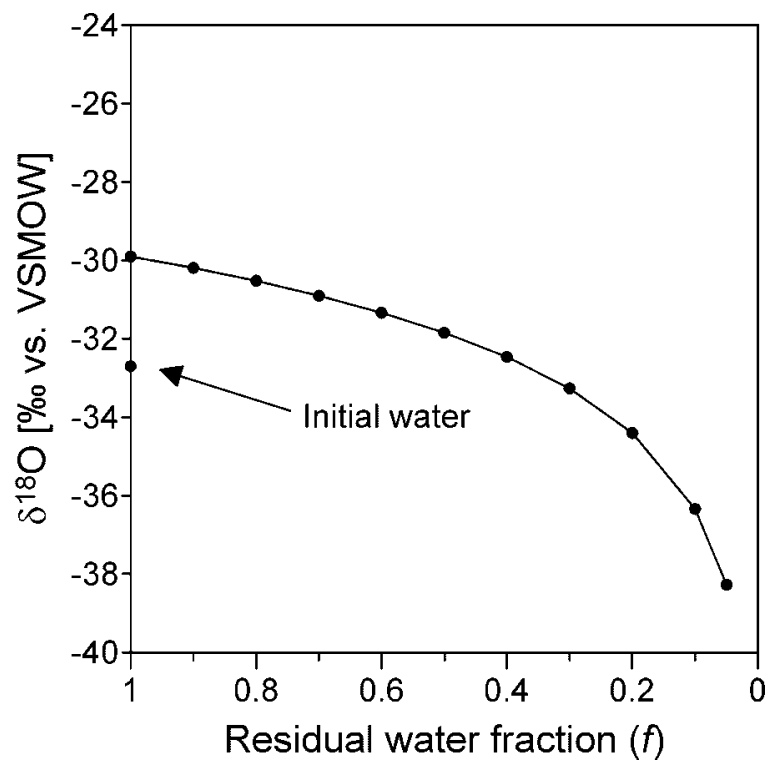

Figure 11 Rayleigh distillation model for the evolution of $\delta^{18} \mathrm{O}$ during equilibrium successive freezing of water. Fractionation coefficients between ice and water are those of Suzuoki and Kimura (1973). Initial $\delta$ values are $-32.7 \%$ and $-252 \%$ for $\delta^{18} \mathrm{O}$ and $\delta \mathrm{D}$, respectively. VSMOW $=$ Vienna Standard Mean Ocean Water.

solutes (and bubbles) are concentrated toward the centre of the ice (Kotler and Burn, 2000) as a result of ionic segregation during freezing. The first fraction to freeze would be closest to the initial ion composition of the parent water. An average EC of $<50 \mu \mathrm{S} / \mathrm{cm}$ for the whole water body is half or less of what is found in recent surface water bodies on Herschel Island fed by precipitation (S. Wetterich, AWI Potsdam, Germany, unpublished data).

When plotted on a $\delta \mathrm{D}-\delta^{18} \mathrm{O}$ diagram, the ice samples form a straight line with a regression slope of 5.9. During equilibrium freezing of water, the resultant ice samples are aligned along a freezing slope that will be lower than the GMWL (Figure 7). Jouzel and Souchez (1982) observed that the slope of the freezing line depends on the initial isotopic composition, with the more depleted waters producing a lower slope value. The initial $\delta$ value of the parent water is the intercept between the freezing slope and the GMWL (Jouzel and Souchez, 1982; Knight, 1997; Souchez et al., 2000). We prefer to use the GMWL as the LMWL for Inuvik reflects contemporary climate conditions and circulation patterns and there is no reconstructed Pleistocene meteoric water line for the area. Following the approach of Jouzel and Souchez (1982) and with calculated initial $\delta$ values of $-251 \%$ and $-32.7 \%$ (for $\delta_{i} \mathrm{D}$ and $\delta_{i}^{18} \mathrm{O}$ ), the theoretical freezing slope $\left[S=S_{0}\left(1000+\delta_{\mathrm{i}} \mathrm{D}\right) /\left(1000+\delta_{i}^{18} \mathrm{O}\right)\right]$ becomes 5.6 which is close to the observed slope. Similarly low freezing slopes attributed to regelation and closed-system freezing have been reported in other studies (e.g. Lorrain and Demeur, 1985; Michel, 1986; Clark and Lauriol, 1997; Souchez et al., 2000; Lacelle et al., 2004, 2009; Murton et al., 2005). 
Interpretation of the slope alone to explain ground ice genesis could be misleading if freezing did not occur under equilibrium conditions (D. Lacelle, University of Ottawa, Canada, personal communication). An examination of the $d-\delta \mathrm{D}$ relation may provide further information. Figure 10 shows that as heavy isotopes become progressively depleted towards the centre of the ice body $d$ values rise. A negative relation between $d$ and $\delta \mathrm{D}$ during equilibrium freezing is expected (Souchez et al., 2000) because the freezing slope has a lower value than the GMWL.

In the case of freezing water, deuterium-excess variability is a result of the freezing conditions (freezing rate, boundary-layer thickness, percentage of freezing of the reservoir (Souchez et al., 2000). Figure 9 shows that as freezing progresses the $\delta \mathrm{D}$ values of the ice become progressively lower. This is accompanied by a concurrent increase in $d$ values (Figure 9) and therefore does account for closed-system freezing. However, the enriched $\delta D$ and $\delta^{18} \mathrm{O}$ values for the outermost portion of the massive ice body are less negative than the isotopic enrichment factor determined by Suzuoki and Kimura (1973) would suggest under Rayleigh-type fractionation. The increasingly negative $\delta$ values are in good agreement with the theoretical Rayleigh fractionation curve (Figure 11). The deviation from the Rayleigh curve may be due to: (i) isotope-exchange processes with porewater of the surrounding sediment, or (ii) kinetic fractionation that occurs during regelation (Zdanowicz et al., 2002). This would imply semi-closed system freezing for the outermost part of the ice body. Sediment incorporation at one edge of the ice body argues at least for the occurrence of some regelation at its margin after ice formation. This is consistent with a heavier isotopic composition at the ice-sediment interface and its deviation from the linear regression slope.

The water feeding the ice body definitely formed during colder climatic conditions than today. It seems likely that the

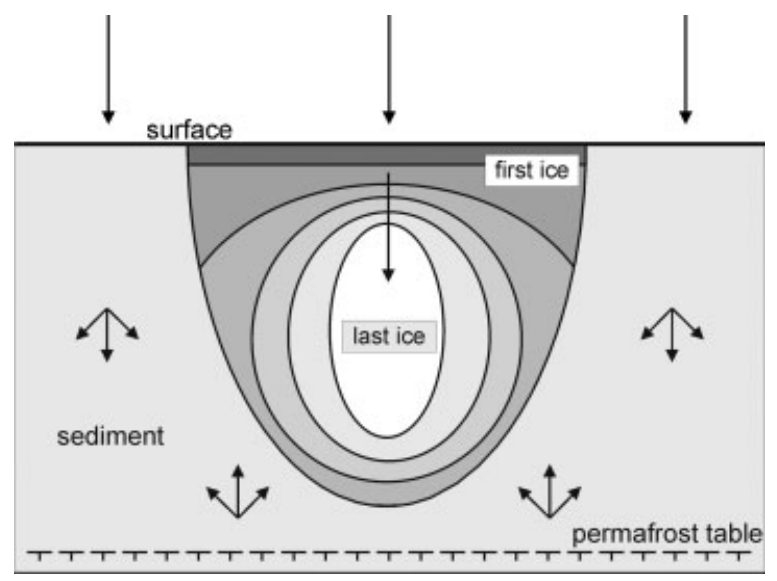

Figure 12 Simplified model of slow closed-system freezing of an enclosed water body under a downward moving freezing front. The different grey levels of the water body show successional freezing. The arrows indicate freezing direction. Already frozen sediments promote the cold wave into unfrozen water. Multilateral freezing of the remaining water occurs. ice body was derived from glacial meltwater in a proglacial area with a retreating glacier front. We infer that a freezing front moved laterally from two sides (Figure 10). Unconformable upper and lateral contacts indicate burial (Mackay, 1989). We suggest that a network of ice-covered proglacial meltwater ponds existed. As the ice cap retreated, permafrost aggraded and enabled slow freezing of the water body from the outside inwards (Figure 12) accompanied by ionic segregation and kinetic fractionation at its margins. Already frozen sediments propagated the freezing front laterally into the more slowly freezing water body. The highly water-saturated diamicton, typical for Herschel Island sediments, could easily have been mobilised in a high-relief glacier forefield to cover frozen water bodies and enable their complete freezing and long-term preservation.

\section{CONCLUSIONS}

The following conclusions can be drawn from this study:

1. Stable isotope $\left(\delta^{18} \mathrm{O}, \delta \mathrm{D}, d\right)$ and hydrochemical investigations, together with cryostratigraphical and cryolithological observations on massive ground ice bodies, can expand the scope of ground ice studies in ice-marginal areas. They provide valuable information on water sources, freezing conditions and postburial landscape development where continuous records are generally rare.

2. Stable isotope signatures indicate a full-glacial water source feeding both massive ground ice bodies examined on Herschel Island.

3. The TSD site massive ice is interpreted as originating as basal regelation glacier ice, evidenced by glaciotectonic deformation structures of an ice-rich diamicton and ice facies similar to those from basal ice layers of contemporary Arctic ice caps. However, an origin as glacially deformed segregated or segregated-intrusive ice cannot be entirely excluded.

4. Basal regelation ice and massive segregated-intrusive ice might coexist in ice-marginal areas. Large parts of the Yukon Coastal Plain may have been characterised by stagnant glacier ice and high-porewater pressures in meltwater-saturated sediments while the glacier front disintegrated.

5. Combined stable isotope and hydrochemical investigations demonstrate a complete freeze through of water leading to the formation of massive ground ice at the HIW site. It is characterised by: (a) Rayleigh-type fractionation; (b) a distinct freezing slope as a consequence of (a); and (c) ionic segregation towards its centre. The range of $\delta^{18} \mathrm{O}$ values measured in this single body of massive ground ice appears to be unprecedented.

\section{ACKNOWLEDGEMENTS}

We wish to express our thanks to the Yukon Territorial Government, the Yukon Parks (Herschel Island Qiqiktaruk 
Territorial Park) and the Yukon Department of Renewable Resources for their support during this project. We acknowledge the support of the Polar Continental Shelf Programme (PCSP/ÉPCP publication number \# 001-08) and the Aurora Research Institute for the field component. This study was partly funded by the German Science Foundation (DFG, Project No. LA 2399/3-1), the German Federal Ministry of
Education and Research (BMBF, Project No. CAN 08/A07, CAN 09/001) and by a doctoral fellowship awarded to Michael Fritz by the German Federal Environmental Foundation (DBU). Analytical work at AWI Potsdam was greatly supported by A. Eulenburg and L. Schönicke. We thank A. Lewkowicz (editor), D. Lacelle and an anonymous reviewer for their helpful comments that improved the manuscript.

\section{REFERENCES}

Bouchard M. 1974. Géologie des dépôts meubles de l'île Herschel, territoire du Yukon. MSc (maitrise) thesis, Université de Montréal, 70pp (in French).

Brezgunov VS, Derevyagin AY, Chizhov AB. 2001. Using natural stable hydrogen and oxygen isotope for studying the conditions of ground ice formation. Water Resources 28: 604-608. DOI: 10.1023/ A:1012825510693.

Cardyn R, Clark ID, Lacelle D, Lauriol B, Zdanowicz C, Calmels F. 2007. Molar gas ratios of air entrapped in ice: A new tool to determine the nature and origin of relict massive ground ice bodies in permafrost. Quaternary Research 68: 239-248. DOI: 10.1016/j.yqres.2007.05.003.

Clark ID, Lauriol B. 1997. Aufeis of the Firth River basin, Northern Yukon insights to permafrost hydrogeology and karst. Arctic and Alpine Research 29: 240-52.

Craig H. 1961. Isotopic variations in meteoric waters. Science 133: 1702-1703. DOI: 10.1126/science.133.3465.1702.

Glacier Oxygen-18 Content and Pleistocene Ocean Temperatures. Science 166: 499502. DOI: 10.1126/science.166.3904.499.

Duk-Rodkin A, Barendregt RW, Froese DG, Weber F, Enkin R, Smith I, Zazula GD, Waters P, Klassen R. 2004. Timing and extent of Plio-Pleistocene glaciations in north-western Canada and east-central Alaska. In Quaternary Glaciations Extent and Chronology, Part II: North America (Developments in Quaternary Science, vol. 2), Ehlers J, Gibbard PL (eds). Elsevier: Amsterdam; 313-346.

Dyke AS, Prest VK. 1987. Late Wisconsinan and Holocene history of the Laurentide Ice Sheet. Géographie Physique et Quaternaire 41: 237-263.

French HM. 1998. An appraisal of cryostratigraphy in north-west Arctic Canada. Permafrost and Periglacial Processes 9: 297-312. DOI: 10.1002/(SICI)1099-1530 (199810/12)9:4<297::AID.-PPP296> 3.0.CO;2-B
French HM, Harry DG. 1990. Observations on buried glacier ice and massive segregated ice, western Arctic coast, Canada. Permafrost and Periglacial Processes 1: 31-43. DOI: 10.1002/ppp.3430010105.

Harris SA. 1989. Landforms and ground ice as evidence of the source of $\mathrm{H}_{2} \mathrm{O}$ in permafrost. Progress in Physical Geography 13: 367-390. DOI: 10.1177/ 030913338901300303.

Hooke RL, Clausen HB. 1982. Wisconsin and Holocene $\delta^{18} \mathrm{O}$ variations, Barnes Ice Cap, Canada. Geological Society of America Bulletin 93: 784-789. DOI: 10.1130/ 0016-7606(1982)93<784:WAHOVB> 2.0.CO;2.

Horita J, Ueda A, Mizukami K, Takaton I. 1989. Automatic $\delta \mathrm{D}$ and $\boldsymbol{\delta}^{18} \mathrm{O}$ analyses of multi-water samples using $\mathrm{H}_{2-}$ and $\mathrm{CO}_{2^{-}}$ water equilibration methods with a common equilibration set-up. Applied Radiation and Isotopes 40: 801-805.

IAEA (International Atomic Energy Agency). 2006. Isotope Hydrology Information System. The ISOHIS Database. http://www.iaea.org/water [accessed 10 February 2010].

Jouzel J, Souchez R. 1982. Melting and refreezing at the glacier sole and the isotopic composition of the ice. Journal of Glaciology 28: 35-42.

Knight PG. 1997. The basal ice layer of glaciers and ice sheets. Quaternary Science Reviews 16: 975-993. DOI: 10.1016/S0277-3791(97)00033-4.

Knight PG, Patterson CJ, Waller RI, Jones AP, Robinson ZP. 2000. Preservation of basal-ice sediment texture in ice-sheet moraines. Quaternary Science Reviews 19: 1255-1258. DOI: $10.1016 / \mathrm{S} 0277-$ 3791(00)00091-3.

Kotler E, Burn CR. 2000. Cryostratigraphy of the Klondike "muck" deposits, west-central Yukon Territory. Canadian Journal of Earth Sciences 37: 849-861. DOI: 10.1139/cjes-37-6-849.

Lacelle D. 2011. On the $\delta^{18} \mathrm{O}, \delta \mathrm{D}$ and D-excess relations in meteoric precipitation and during equilibrium freezing: theoretical approach and field examples. Permafrost and Periglacial Processes DOI:10.1002/ppp.712.

Lacelle D, Bjornson J, Lauriol B, Clark ID, Troutet Y. 2004. Segregated-intrusive ice of subglacial meltwater origin in retrogressive thaw flow headwalls, Richardson Mountains, NWT, Canada. Quaternary Science Reviews 23: 681-696. DOI: 10.1016/j.quascirev.2003.09.005.

Lacelle D, Lauriol B, Clark ID, Cardyn R, Zdanowicz Ch. 2007. Nature and origin of a Pleistocene-age massive ground-ice body exposed in the Chapman Lake moraine complex, central Yukon Territory, Canada. Quaternary Research 68: 249 260. DOI: 10.1016/j.yqres.2007.05.002.

Lacelle D, Lauriol B, Clark ID. 2009. Formation of seasonal ice bodies and associated cryogenic carbonates in Caverne de l'Ours, Quebec, Canada: Kinetic isotope effects and pseudobiogenic crystal structures. Journal of Cave and Karst Studies 71: 48-62.

Lantuit H, Pollard WH. 2005. Temporal stereophotogrammetric analysis of retrogressive thaw slumps on Herschel Island, Yukon Territory. Natural Hazards and Earth System Science 5: 413-423.

Lantuit H, Pollard WH. 2008. Fifty years of coastal erosion and retrogressive thaw slump activity on Herschel Island, southern Beaufort Sea, Yukon Territory, Canada. Geomorphology 95: 84-102. DOI: 10.1016/j.geomorph.2006.07.040.

Lorrain RD, Demeur P. 1985. Isotopic evidence for relic Pleistocene glacier ice on Victoria Island, Canadian Arctic Archipelago. Arctic and Alpine Research 17: 8998. DOI: $10.2307 / 1550964$.

Mackay JR. 1959. Glacier ice-thrust features of the Yukon Coast. Geographical Bulletin 13: 5-21.

Mackay JR. 1971. The origin of massive icy beds in permafrost, western arctic coast, Canada. Canadian Journal of Earth Sciences 8: 397-422. DOI: 10.1139/e71043. 
Mackay JR. 1972. Offshore permafrost and ground ice, southern Beaufort Sea, Canada. Canadian Journal of Earth Sciences 9: 1550-1561. DOI: 10.1139/ e72-137.

Mackay JR. 1983. Oxygen isotope variations in permafrost, Tuktoyaktuk peninsula area, Northwest Territories. Geological Survey of Canada, Current Research Part B (Paper 83-1B): 67-74.

Mackay JR. 1989. Massive ice: some field criteria for the identification of ice types. Geological Survey of Canada, Current Research Part G (Paper 89-1G): 5-11.

Mackay JR, Dallimore SR. 1992. Massive ice of the Tuktoyaktuk area, western Arctic coast, Canada. Canadian Journal of Earth Sciences 29: 1235-1249. DOI: 10.1139/ e92-099.

Meyer H, Schönicke L, Wand U, Hubberten H-W, Friedrichsen H. 2000. Isotope studies of hydrogen and oxygen in ground ice - Experiences with the equilibration technique. Isotopes in Environmental and Health Studies 36: 133-149.

Meyer H, Dereviagin AY, Siegert C, Hubberten H-W. 2002. Paleoclimate studies on Bykovsky Peninsula, North Siberia hydrogen and oxygen isotopes in ground ice. Polarforschung 70: 37-51.

Michel FA. 1986. Isotope geochemistry of frost-blister ice, North Fork Pass, Yukon, Canada. Canadian Journal of Earth Sciences 23: 543-549. DOI: 10.1139/ e86-054.

Michel FA, Fritz P. 1978. Environmental isotopes in permafrost related waters along the Mackenzie Valley corridor. In Proceedings of the Third International Conference on Permafrost. National Research Council of Canada: Edmonton, Canada; 252-255.

Michel FA, Fritz P. 1983. Isotope variations in permafrost waters along the Dempster Highway Pipeline corridor. In Proceedings of the Fourth International Conference on Permafrost, French HM (ed.). National
Research Council of Canada: Fairbanks, Alaska; 843-848.

Moorman BJ, Michel FA, Wilson AT. 1998. The development of tabular massive ground ice at Peninsula Point, N.W.T., Canada. In Proceedings of the Seventh International Conference on Permafrost, Lewkowicz AG, Allard M (eds). Collection Nordicanada No. 57. Yellowknife, Canada, June 1998; 757-762.

Murton JB, Whiteman CA, Waller RI, Pollard WH, Clark ID, Dallimore SR. 2005. Basal ice facies and supraglacial melt-out till of the Laurentide Ice Sheet, Tuktoyaktuk Coastlands, western Arctic Canada. Quaternary Science Reviews 24: 681-708. DOI: $10.1016 /$ j.quascirev.2004.06.008.

Pollard WH. 1990. The nature and origin of ground ice in the Herschel Island area, Yukon Territory. In Proceedings of the Fifth Canadian Permafrost Conference. Collection Nordicanada, No. 54. Centre d'études Nordiques, Université Laval, Québec: Nordicana Québec; 23-30.

Rampton VN. 1982. Quaternary geology of the Yukon Coastal Plain. Geological Survey of Canada Bulletin 317, 49pp.

Rampton VN. 1988. Quaternary geology of the Tuktoyaktuk coastlands, Northwest Territories. Geological Survey of Canada Memoir 423, 98pp.

Rampton VN. 2001. Major end moraines of Younger Dryas age on Wollaston Peninsula, Victoria Island, Canadian Arctic: implications for paleoclimate and for formation of hummocky moraine: Discussion. Canadian Journal of Earth Sciences 38: 1003-1006. DOI: 10.1139/ cjes-38-6-1003.

Smith CAS, Kennedy CE, Hargrave AE, McKenna KM. 1989. Soil and vegetation of Herschel Island, Yukon Territory. Yukon Soil Survey Report No. 1. Land Resource Research Centre, Agriculture Canada, Ottawa.

Smith SL, Burgess MM. 2000. Ground temperature database for northern Canada.
Geological Survey of Canada Open File Report 3954, 57pp.

Souchez RA, Lemmens M, Lorrain R, Tison JL, Jouzel J, Sugden D. 1990. Influence of hydroxyl-bearing minerals on the isotopic composition of ice from the basal zone of an ice sheet. Nature 345: 244-246. DOI: $10.1038 / 345244 \mathrm{a} 0$.

Souchez RA, Jouzel J, Lorrain R, Sleewaegen S, Stiévenard M, Verbeke V. 2000. A Kinetic Isotope Effect During Ice Formation by Water Freezing. Geophysical Research Letters 27: 1923-1926. DOI: 10.1029/2000GL006103.

Sugden DE, Knight PG, Livesey N, Lorrain RD, Souchez RA, Tison JL, Jouzel J. 1987. Evidence for two zones of debris entrainment beneath the Greenland ice sheet. Nature 328: 238-241. DOI: 10.1038/ $328238 \mathrm{a} 0$.

Suzuoki T, Kimura T. 1973. D/H and ${ }^{18} \mathrm{O} /{ }^{16} \mathrm{O}$ fractionation in ice-water systems. Mass Spectroscopy 21: 229233.

Vasil'chuk YK, Vasil'chuk AC. 1997. Radiocarbon Dating and Oxygen Isotope Variations in Late Pleistocene Syngenetic IceWedges, Northern Siberia. Permafrost and Periglacial Processes 8: 335-345. DOI: 10.1002/(SICI)1099-1530(199709)8:3< 335::AID.-PPP259>3.0.CO;2-V

von Toll EV. 1897. Iskopaemye ledniki NovoSibirskikh ostrovov, ikh otnoshenie k trupam mamontov i $\mathrm{k}$ lednikovomu periodu (Ancient glaciers of New Siberian Islands, their relation to mammoth corpses and the Glacial period). Zapiski Imperatorskogo Russkogo Geograficheskogo obshestva po obshei geografi (Notes of the Russian Imperial Geographical Society) 32: 1-137 (in Russian).

Zdanowicz Ch, Fisher DA, Clark I, Lacelle D. 2002. An ice-marginal ${ }^{18} \mathrm{O}$ record from Barnes Ice Cap, Baffin Island, Canada. Annals of Glaciology 35: 145-149. DOI: 10.3189/172756402781817031. 